\title{
Effectiveness of Nursing Intervention Measures on Minimizing Puerperal Mastitis and promoting breast feeding
}

\author{
Eman Mohammed Abd Elhakam and Somaya Ouda Abd Elmoniem \\ Lecturers in Maternal and Newborn Health Nursing, Faculty of Nursing , Benha University, Egypt.
}

\begin{abstract}
Mastitis is a significant common problem in lactating women and may contribute to weaning in the first three weeks. Mastitis has been reported as the third most common reason for weaning.

The Aim of the study was to evaluate the effectiveness of nursing intervention measures on minimizing Puerperal mastitis and promoting breast feeding.

Material and Methods: The study was conducted at gynecological outpatient clinic at Benha University Hospital.The study design was a quasi experimental design. Purposive sample of 120 mothers selected randomly and divided into two equal group (60 study group \& 60 control group).

Tools of Data Collection were interviewing questionnaire sheet. Observational \& follow up check list.

Results of this study revealed that, mean age 25.2 \pm 5.0 years of study group and $24.6 \pm 4.7$ of Control Group with higher in percentage in age group $(20-25)$ years $(45.0 \%, 33.3 \%)$ in study and control group respectively with non-significance difference $(P>0.05)$ in follow up antenatal care $(36.7 \%$ \& $25.0 \%)$ in study and control groups respectively. With highly significance difference $(P<0.001)$ between study \& control groups post intervention in knowledge of both importance of breast feeding, importance of colostrum milk, number of breast feeding /day, the ideal way to breast feeding and indicators of their infant hunger between study \& control groups. Also there were highly significant difference $\left(p<0.001^{* *}\right)$ between both groups in post intervention the most of study group $(86.7 \%, 83.3 \%, 88.3 \%, 96.7 \%)$ recovery from pain, redness, edema and pyrexia with highly significance difference $(P<0.000)$ between knowledge and practice post intervention. more than one third the nurse $(38.3 \% ; 35 \%)$ is the main source of knowledge about breastfeeding.

Conclusion: nursing intervention was more effective and contributed rapid recovery from mastitis. The breastfeeding intervention of health care professionals must be adapted to an effective program, 20-hour breastfeeding training course, and puerperal mastitis should be accepted as a public health care issue.
\end{abstract}

Keywards: Puerperal Mastitis, nursing intervention, breast feeding.

\section{Introduction}

Puerperal mastitis is defined as an infection of the tissue of the breast that occurs most commonly during the time of breastfeeding. It can occur when bacteria, often from the baby's mouth, enter a milk duct through a crack in the nipple. Breast infections most commonly occur one to three months after the delivery of a baby, but they can occur in women who have not recently delivered as well as in women after menopause. (Amir,2014). Mastitis is especially problematic because it may lead to the discontinuation of breast-feeding, which provides optimal infant nutrition the incidence of mastitis varies widely across populations, likely because of variations in breastfeeding methods and support (Spencer, 2014).

The incidence of puerperal mastitis varies greatly; according to studies, mastitis seems to affect approximately $10 \%$ of all breastfeeding mothers. However, study results have varied significantly, some indicating only $3 \%$ while others say $33 \%$ of women are affected. It is commonest in the second and third week postpartum with most reports indicating that $74 \%$ to $95 \%$ of cases occur in the first 12 weeks However, it may occur at any stage of lactation, including in the second year (Jahanfar et al 2010, Kelly A. McGarry2012).

The usual clinical picture of mastitis is a tender, hot, swollen, wedge-shaped area of breast associated with a temperature of $38.5^{\circ} \mathrm{C}$ or greater, chills, flu-like aching, and systemic illness (Lawrence, 2008).Two types of mastitis most commonly, Non-infectious mastitis - is usually caused by milk stasis (milk is produced, but then remains in the breast, rather than coming out during feeding). Milk stasis may have the following causes: The baby is not attaching effectively to the breast properly during feeding. The baby has difficulties suckling the milk out of the breast. The baby is being breastfed infrequently. Milk ducts may be blocked due to pressure on the breast as in tight clothing. Anything which stops the milk from being properly expressed will usually result in milk stasis, which often leads to milk duct blockage .On the other hand causes of infectious mastitis, Bacteria do not generally thrive in fresh human milk. However, if the milk ducts are blocked and the milk stagnates the likelihood of infection grows. Experts believe that bacteria which exist on the surface of breast skin enter the breast through small cracks or breaks in the skin. They also suggest that bacteria in the baby's mouth may get into the mother's breast during a breastfeed. However, nobody is completely sure how 
bacteria get into the breast (Walker,2009). The diagnosis of mastitis is usually clinical, with patients presenting with focal tenderness in one breast accompanied by fever and malaise(Jeanne \& Spencer, 2008).

Nursing intervention measures are aimed to increasing comfort and helping the mother maintain lactation. Because milk stasis is often the initiating factor in mastitis, the most important management step is frequent and effective milk removal. Mothers should be encouraged to breastfeed more frequently, starting on the affected breast .If pain prohibits letdown, feeding may begin on the unaffected breast, switching to the affected breast as soon as let down is achieved. Moist heat promotes comfort and increases circulation (Christensen \& Kockrow ,2011).

Another effective applied technique is achieved by Applying slices of raw potato with in the first 24 hours of symptoms beginning to the breast will reduce the pain, swelling, and redness of mastitis. This by cutting 6 to 8 washed raw potatoes lengthwise into thin slices. Place in a large bowl of water at room temperature and leave for 15 to 20 minutes. Apply the wet potato slices to the affected area of the breast and leave for 15 to 20 minutes. Remove and discard after 15 to 20 minutes and apply new slices from the bowl. Repeat this process two more times so that you have applied potato slices 3 times in an hour. Take a break for 20 or 30 minutes and then repeat the procedure (Newman, 2009). Use of heat packs before and cold packs after breastfeeding reduce inflammation and facilitate the drainage of milk from the breast (Crepinsek et al,2012).

Breastfeeding or pumping every 1.5 to 2 hours and correct positioning of baby makes the mother more comfortable and prevent stasis. Starting the feeding on the unaffected side causes the milk ejection reflex to occur in both breasts making milk available in the painful breast as soon as the infant begins to nurse on that side. Massage over the affected area before and during the feeding helps to ensure complete emptying. The mother should stay in bed during the acute phase of her illness. Her fluid intake should increase, be 2500 to 3000ml. per day (McKinney \&Murray, 2014).

Prompt attention to any signs of milk stasis, if the mother notices any signs of milk stasis, she needs to rest, increase the frequency of breastfeeding, apply heat to the breast prior to feedings, and massage any lumpy areas as described under "Effective milk removal.", mothers should seek help from their health care provider if they are not improving within 24 hours. On the other hand, Prompt attention to other difficulties with breastfeeding, skilled help is needed for mothers with damaged nipples or an unsettled infant or those who believe that they have an insufficient milk supply(Waldenstrom\& Aarts,2011).

As fatigue is often a precursor to mastitis, health professionals should encourage breastfeeding mothers to obtain adequate rest. It may be helpful for health care providers to remind family members that breastfeeding mothers may need more help and encourage mothers to ask for help as necessary (Neifert,2006). Good hygiene is also the most important management step, because $S$. aureus is a common commensal organism often present in hospitals and communities, the importance of good hand hygiene should not be overlooked. It is important for hospital staff, new mothers, and their families to practice good hand hygiene. Pump equipment may also be a source of contamination and should be washed thoroughly with soap and hot water after use(Andrews,etal.2007).

\section{Significant of the study:}

Mastitis is a significant complication and is a common problem in Lactating women and may contribute to weaning in the first three weeks. Mastitis has been reported as the third most common reason for weaning (Michie 2013) babies who are not breastfed are predisposed to many health complications in later life, including high blood pressure, obesity, non-insulin dependent diabetes and ischemic heart disease (Thompson 2009). The short- and long-term benefits of breastfeeding to the mother include the increase of uterine contractions post-delivery, resulting in a reduction of postpartum bleeding. Breastfeeding also enhances a faster return to the pre-pregnant body weight as well as possible protection against osteoporosis, ovarian and uterine cancer despite the recognized health, emotional, psychosocial and societal benefits of breastfeeding to women and children, breastfeeding rates worldwide are sub-optimal, especially among low-income women. Increasing breastfeeding initiation and duration amongst low-income women would not only offer improved health benefits to both the mother and infant, but would lessen the economic burden experienced by this group of people within the community.

\section{Aim of the Study:}

This study aimed to evaluate the effectiveness of nursing intervention measures on minimizing Puerperal mastitis and promoting breast feeding.

\section{Hypotheses of the study:}

Puerperal mother's with lactational mastitis that applying nursing intervention measures after training minimize mastitis early and enhance breastfeeding compared to those who do not apply this measure.

\section{Subjects and Methods:}

Study design: This study was a quasi experimental design. 
Setting: The study was carried out at gynecological outpatient clinic at Benha University Hospital.

Sample type: Purposive sample.

Sample size:

The total size was 120 women purposefully divided into two equal groups. (60 for each group). The control group were included the first 60 mothers who received the routine hospital care, While the next 60 mother were included in the study group who suffers from puerperal mastitis. They were trained to apply nursing intervention measures of puerperal mastitis to minimize mastitis and enhance breast feeding.

Sample criteria: women in the first few weeks postpartum, within the first 24 hours symptoms beginning, breast feeding mother, the baby is normal without any abnormalities affect breast feeding as cleft lip or others, mother free from medical disease which interfere with breastfeeding.

Exclusion criteria: Any congenital abnormalities in the baby affect breast feeding as cleft lip and cleft palate.

\section{Sample technique:}

The Women attending gynecological outpatient clinic are randomly selected with sample criteria were interviewed and included in the study, during July 2014 to the end of December 2014.

\section{Ethical consideration:}

- Each subject was informed that:

- Informed about the nature, process and expected outcomes of the study.

- All subject's rights was secured.

- Reassured that the study was harmless.

- All data were confidential and were used only for research purpose.

- Each subject was free to withdraw from the study at any time.

Tools:

1-An interviewing questionnaire sheet:

A-The socio demographic characteristic of the women includes: age, level of education, phone number, address, occupation and residence.

B- Obstetric history of women: History of Previous Pregnancies, Number of pregnancies and outcomes,

C-Breast feeding history

D-Their knowledge regarding puerperal mastitis (risk factors, causes, clinical picture, prevention and management)

E- Their knowledge regarding nursing intervention measures of puerperal mastitis.

Scoring System for women's Knowledge:-

Puerperal women's Knowledge about breast feeding and mastitis. The answer of the questions were divided into two categories, these were correct and incorrect answer.
a. $0=$ incorrect answer.
b. $1=$ correct answer.

The correct answer was classified as the follows:-

Good $\geq 75 \%$ correct answer.

Average from $50 \%$ to $<75 \%$ correct answer.

Poor $<50 \%$ correct answer.

\section{2-Obsevational checklist sheet including four charts:}

A- Visual analog scale: it was used to assess four levels of pain :- $0=$ no pain, $1=$ mild pain, $2=$ moderate pain, 3 $=$ severe pain.

B-Newton's scale (1951) which entails measuring chest circumference just above the nipple in order to assess breast edema Breast edema was determined through four levels:- $0=$ no edema, $1=$ mild edema., $2=$ moderate edema,3 = severe edema.

C- Pyrexia chart: in order to assess body temperature Pyrexia was assessed through four levels: $-0=37-0 \mathrm{c}$ (no pyrexia), $1=37.5-0 \mathrm{c} \quad$ (mild pyrexia), $2=38-0 \mathrm{c}($ moderate pyrexia) $.3=38.5-0 \mathrm{c}$ (severe pyrexia).

D- Modified Reeda scale: was used to assess degree of redness as $0=$ no redness, $1=$ mild redness, $2=$ moderate redness, 3 = severe redness.

\section{Field Work (Procedure):-}

Field study was conducted during the period from the beginning July 2014 to the end of December 2014. The researchers attended gynecological outpatient clinic three days weekly to collect the data by using previous tools until the predetermined numbers were fulfilled. The researchers select postpartum women who fulfilled the criteria. The researchers explained the purpose of the study to every woman, and then her consent to participate in the study was obtained. Each interview was conducted individually and in total privacy to assure that information to be obtained will be confidential and will be used only for research purpose. The time taken for each sheet to complete was 30-60 minutes, depending upon the response of interviewer. The study proceeds as the following:- The researchers are interviewed by Postpartum women Within the first 24 hours of symptoms

DOI: 10.9790/1959-0505055565 $\quad$ www.iosrjournals.org $57 \mid$ Page


beginning at gynecological outpatient clinic and assess their knowledge about breastfeeding and mastitis. In addition, the condition of their breasts was assessed during the initial interview according to the pre-designed check list which is used on the Newton's Scale.

Group (1):- Study group: group comprised half of mother (60 women) who suffers from puerperal mastitis. They were trained to apply nursing intervention measures of puerperal mastitis to minimize mastitis and enhance breast feeding. Types of nursing intervention applied:-

- Appling of warm compresses for affected breast for 20 minutes before each feeding. Heat application is used in form of hot compresses, hot shower, or hot soaks.

- Use of cold packs (slice of raw potato) after breastfeeding may find that applying slices of raw potato to the breast will reduce the pain, swelling, and redness of mastitis.

- Cut 6 to 8 washed raw potatoes lengthwise into thin slices.

- Place in a large bowl of water at room temperature and leave for 15 to 20 minutes.

- Apply the wet potato slices to the affected area of the breast and leave for 15 to 20 minutes.

- Remove and discard after 15 to 20 minutes and apply new slices from the bowl.

- Repeat this process two more times so that you have applied potato slices 3 times in an hour.

- Take a break for 20 or 30 minutes and then repeat the procedure.

- Massaging the breast and emptying the breast by manual (or pump) expression of milk after each feeding was demonstrated at first by the researcher on one breast and re demonstrated by the mother on the other breast.

- Frequency of breastfeeding;

- Correct positioning of baby at the breast

- Increase fluid intake

- Increase intake of vitamin c

Group (2): Control group: this group was comprised the other half of the mothers (60 women) who suffer from puerperal mastitis and they were left for the routine post natal hospital.

Follow up:-

Reassessment of women's breast for (redness, edema, and pain) and the mother observed for pyrexia; using the same tools which were used in the 1st visit; was done for two groups at 3rd, 4th,and 5th day postpartum , and they instructed to come to outpatient clinic for follow-up visits at 7th, and 9th day postpartum.

\section{Pilot study:}

It was carried out on $10 \%$ of the sample (12 women) to clarify the validity and reliability of the questionnaire and then modification was done, through the interview of woman individually in the outpatient clinic of obstetrics and gynecological department to evaluate effectiveness of nursing intervention on puerperal mastitis.

\section{Statistical design}

Data were verified prior to computerized entry. The statistical package for social sciences (SPSS version 21.0) was used for that purpose, followed by data analysis and tabulation. The following statistical measures were used, descriptive measures which include frquency, percentages, means, standard deviation. Test of significance (Chi-Square test) test for analysis of qualitative variables test for analysis of quantitative variables test for analysis of correlation association.

\section{Results}

Table (1) shows distribution of demographic data in study \& control groups. that mean age $25.2 \pm 5.0$ years of study group and $24.6 \pm 4.7$ of Control Group with higher in percentage in age group (20-25)years $(45.0 \%, 33.3 \%)$ in study and control group respectively with non significance difference $(\mathrm{P}>0.05)$. Also about half of cases in study and control in secondary equivalent education $(46.7 \% \& 43.3 \%)$ in both study \& control groups with non significance difference $(\mathrm{P}>0.05)$. As regard there were non significance difference in occupation $(\mathrm{P}>0.05)$ with about third of cases in each group study \& control groups $(61.7 \%$ \& $58.3 \%)$ working in each study \& control. Also illustrated that about third of cases from urban $(33.3 \% \& 31.7 \%)$ study \& control groups with non significance difference and about family size $(\mathrm{P}>0.05)$.

Table (2) shows distribution of the Samples according to their follow up antenatal care revealed that Non-significance difference $(\mathrm{P}>0.05)$ in follow up antenatal care with $(36.7 \%$ \& $25.0 \%)$ in study and control groups respectively. Also there were non significance in number of antenatal visit and knowledge about breast feeding problem $(\mathrm{P}>0.05)$.

Table (3) shows distribution of the Samples according to their knowledge about the Breast Feeding. With statistical significance difference $(\mathrm{P}<0.001)$ between study \& control groups post intervention in knowledge of both importance of breast feeding comparing \& importance of colostrum milk between study \& 
control groups. As regard there were highly statistically significant difference $(p<0.001)$ in each number of breast feeding /day, the ideal way to breast feeding and indicators of their infant hunger post intervention between study \& control groups.

Table (4) illustrates comparison effect of intervention in practice between study \& control pre and post intervention. With non signifcance difference pre intervention between study \& control groups $(\mathrm{P}>0.05)$. But there were highly signifcance difference $(\mathrm{P}<0.001)$ post intervention in each item of practice regarding breast feeding such breast hygiene before feeding, newborn positions during feeding, position of the mouth, breast feeding is practiced and duration of lactation.

Table (5) illustrates the distribution of mothers pre and post intervention ' regards Knowledge about the mastitis between study and control group. The analysis of findings reveals that, there was a statistical significant difference $\left(\mathrm{p}<0.001^{* *}\right)$ of mothers' knowledge in all items concerning mastitis in the postnatal period after application of the intervention between both groups . meanwhile there was insignificant difference between both groups at pre interventions.

Table (6) shows that, there was insignificant difference pain, redness, edema and pyrexia between study and control group in pre intervention. Also revealed highly significant difference $(\mathrm{p}<\mathbf{0 . 0 0 1} * *)$ between both groups in post intervention the most of study group $(86.7 \%, 83.3 \%, 88.3 \%, 96.7 \%)$ recovery from pain, redness, edema and pyrexia

Table (7) shows relation between total knowledge "pre" Practice and total practice pre intervention improvement between study and control group pre intervention. With highly signifcance difference $(\mathrm{P}<0.001)$ between knowledge and practice pre intervention in each study \& control groups . In study group there were $(100 \%)$ of poor knowledge have average practice and $(91.5 \%)$ in average knowledge in poor practice in study group . As regard in control group there were $(89.8 \%)$ in average knowledge have average practice.

Table (8) shows relation between total knowledge "post" Practice and total practice post intervention improvement between study and control group post intervention. With highly signifcance difference $(\mathrm{P}<0.001)$ between knowledge and practice post intervention. With $(94.1 \%)$ in good knowledge have good practice in study group, but in control group (63.6\%) in good knowledge in good practice after intervention.

Table (1): Distribution of the Samples According To Their General Characteristics.

\begin{tabular}{|c|c|c|c|c|c|c|}
\hline \multirow[t]{3}{*}{ Variables } & \multicolumn{4}{|c|}{ Sample groups } & \multirow{3}{*}{$\begin{array}{c}\mathbf{X}^{2} \\
\text { Test }\end{array}$} & \multirow{3}{*}{$P$ value } \\
\hline & \multicolumn{2}{|c|}{$\begin{array}{c}\text { Study Group } \\
(n=60)\end{array}$} & \multicolumn{2}{|c|}{$\begin{array}{c}\text { Control Group } \\
(n=60)\end{array}$} & & \\
\hline & $\mathrm{N}$ & $\%$ & $\mathrm{~N}$ & $\%$ & & \\
\hline \multicolumn{5}{|l|}{ Age( in years) } & \multirow[t]{6}{*}{2.71} & \\
\hline$<20$ & 8 & 13.3 & 12 & 20.0 & & \\
\hline $20-$ & 27 & 45.0 & 20 & 33.3 & & 0.60 \\
\hline $25-$ & 9 & 15.0 & 13 & 21.7 & & \\
\hline $30-40$ & 16 & 26.7 & 15 & 25.0 & & \\
\hline Mean $\quad \mathrm{X}- \pm$ SD & \multicolumn{2}{|c|}{$25.2 \pm 5.0$} & \multicolumn{2}{|c|}{$24.6 \pm 4.7$} & & \\
\hline \multicolumn{5}{|l|}{ Education: } & \multirow{5}{*}{1.18} & \\
\hline Illiteracy & 3 & 5.0 & 4 & 6.7 & & \\
\hline Read \& write + Basic education & 9 & 15.0 & 6 & $\mathbf{1 0 . 0}$ & & 0.75 \\
\hline Secondary equivalent education & 28 & 46.7 & 26 & 43.3 & & \\
\hline University education & 20 & 33.3 & 24 & 40.0 & & \\
\hline \multicolumn{5}{|l|}{ Occupation: } & \multirow[t]{3}{*}{0.139} & \\
\hline Working & 23 & 38.3 & 25 & 41.7 & & 0.70 \\
\hline Housewife & 37 & 61.7 & 35 & 58.3 & & \\
\hline \multicolumn{5}{|l|}{ Residence: } & \multirow[t]{3}{*}{$\mathbf{0 . 0 3}$} & \\
\hline Urban & 20 & 33.3 & 19 & 31.7 & & 0.8 \\
\hline Rural & 40 & 66.7 & 41 & 68.3 & & \\
\hline \multicolumn{5}{|l|}{ Family Size: } & \multirow{4}{*}{0.40} & \\
\hline$<4$ & 31 & 51.7 & 29 & 48.3 & & \\
\hline 4- 5 & 24 & 40.0 & 24 & 40.0 & & .81 \\
\hline$>5$ & 5 & 8.3 & 7 & 11.7 & & \\
\hline
\end{tabular}

Table (2): Distribution of the Samples According To Their Follow up Antenatal Care (n=60).

\begin{tabular}{|c|c|c|c|c|c|c|}
\hline \multirow[t]{3}{*}{ Variables } & \multicolumn{4}{|c|}{ Sample groups } & \multirow[t]{3}{*}{$\mathrm{X}^{2}$ Test } & \\
\hline & \multicolumn{2}{|c|}{$\begin{array}{l}\text { Study Group } \\
(\mathrm{n}=60)\end{array}$} & \multicolumn{2}{|c|}{\begin{tabular}{|c|} 
Control Group \\
$(\mathbf{n}=60)$
\end{tabular}} & & $P$ value \\
\hline & $\mathrm{N}$ & $\%$ & $\mathrm{~N}$ & $\%$ & & \\
\hline \multicolumn{5}{|l|}{ Follow Up Antenatal Care: } & \multirow{3}{*}{1.9} & \\
\hline - $\quad$ Yes & 38 & 63.3 & 45 & 75.0 & & $0.1^{*}$ \\
\hline - $\quad \mathrm{No}$ & 22 & 36.7 & 15 & 25.0 & & \\
\hline Reasons For not Seeking Antenatal Care & \multicolumn{2}{|c|}{$\mathbf{n}=\mathbf{2 2}$} & \multicolumn{2}{|c|}{$n=15$} & & \\
\hline Lack of awareness about antenatal care services & 3 & 13.6 & 0 & 0.0 & \multirow[t]{2}{*}{19.28} & \\
\hline Lack of money (Financial factor) & 4 & 18.2 & 9 & 60.0 & & \\
\hline
\end{tabular}




\begin{tabular}{|c|c|c|c|c|c|c|}
\hline Have no decision making power & 3 & 13.6 & 3 & 20.0 & & \\
\hline Waist of time (Long waiting \& over crowding center) & 6 & 27.3 & 3 & 20.0 & & 0.02* \\
\hline Difficult transportation & 6 & 27.3 & 0 & 0.0 & & \\
\hline For high risk cases only\& Absence of health problems & 0 & 0.0 & 0 & 0.0 & & \\
\hline Number Of Antenatal Visit: & \multicolumn{2}{|c|}{$\mathbf{n}=38$} & \multicolumn{2}{|c|}{$\mathrm{n}=45$} & \multirow[t]{3}{*}{$\mathbf{1 . 5 8}$} & $\mathbf{0 . 2 0}$ \\
\hline - $<4$ time & 23 & 60.5 & 21 & 46.7 & & \\
\hline - $\quad \geq 4$ time & 15 & 39.5 & 24 & 53.3 & & \\
\hline Knowledge About Breast Feeding Problem & 9 & 23.7 & 9 & 20.0 & \multirow[t]{3}{*}{0.16} & .68 \\
\hline - $\quad$ Yes & & & & & & \\
\hline - $\quad$ No & 29 & 76.3 & 36 & 80.0 & & \\
\hline
\end{tabular}

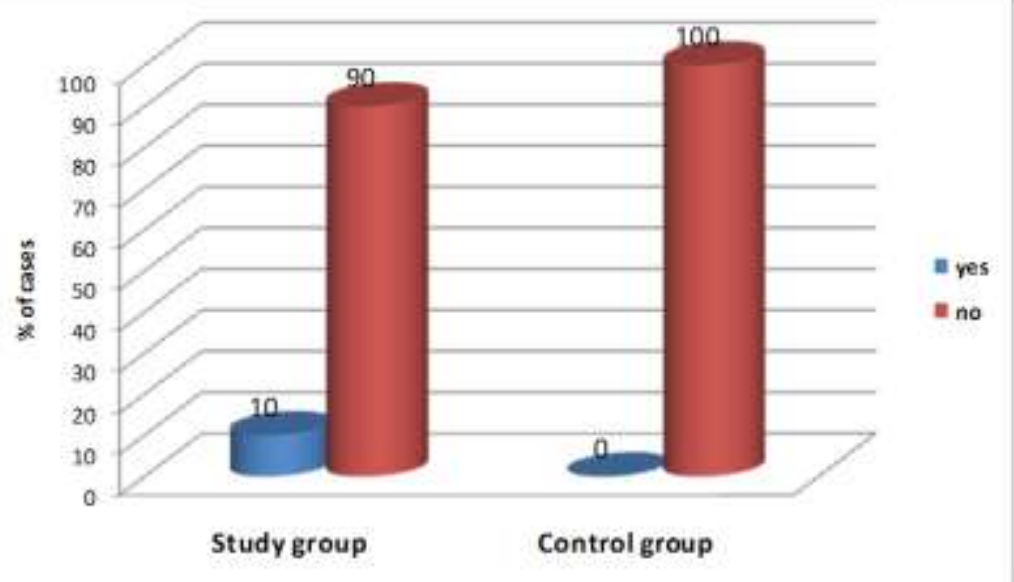

Figure (1): Percentage distribution of mothers regarding to Breast Preparation during Pregnancy

Table (3): Distribution of the Samples According To Their Knowledge about the of Breast Feeding.

\begin{tabular}{|c|c|c|c|c|c|c|c|c|}
\hline \multirow[t]{3}{*}{ Variable } & \multicolumn{4}{|c|}{$\begin{array}{c}\text { Pre } \\
\text { intervention }\end{array}$} & \multicolumn{4}{|c|}{$\begin{array}{c}\text { Post } \\
\text { Intervention }\end{array}$} \\
\hline & \multicolumn{2}{|c|}{$\begin{array}{c}\text { Study group } \\
\mathbf{n}=\mathbf{6 0}\end{array}$} & \multicolumn{2}{|c|}{$\begin{array}{c}\text { Control group } \\
\mathbf{n}=60\end{array}$} & \multicolumn{2}{|c|}{$\begin{array}{c}\text { Study group } \\
\mathbf{n}=\mathbf{6 0}\end{array}$} & \multicolumn{2}{|c|}{$\begin{array}{c}\begin{array}{c}\text { Control group } \\
n=60\end{array} \\
\end{array}$} \\
\hline & No & $\%$ & No & $\%$ & No & $\%$ & No & $\%$ \\
\hline \multicolumn{9}{|l|}{ Importance Of Breast Feeding: } \\
\hline . Complete \& Correct & 15 & 25 & 16 & 26.7 & 52 & 86.7 & 21 & 35.0 \\
\hline - Incomplete \&Correct & 42 & 70.0 & 44 & 73.3 & 8 & 13.3 & 39 & 65.0 \\
\hline - $\quad$ Don't Know \& incorrect & 3 & 5.0 & $\mathbf{0}$ & 0.0 & $\mathbf{0}$ & 0.0 & $\mathbf{0}$ & $\mathbf{0 . 0}$ \\
\hline X2 \& p value & \multicolumn{4}{|c|}{3.07} & \multicolumn{2}{|r|}{33.61} & \multicolumn{2}{|c|}{$<0.001 * *$} \\
\hline \multicolumn{9}{|l|}{ Importance of Colostrum Milk } \\
\hline - $\quad$ Complete \& Correct & 6 & 10.0 & 10 & 16.7 & 45 & 75.0 & 11 & 18.3 \\
\hline - Incomplete \&Correct & 48 & 80.0 & $\mathbf{5 0}$ & 83.3 & 15 & 25.0 & 49 & 81.7 \\
\hline - $\quad$ Don't Know \& incorrect & 6 & $\mathbf{1 0 . 0}$ & $\mathbf{0}$ & 0.0 & $\mathbf{0}$ & 0.0 & $\mathbf{0}$ & 0.0 \\
\hline X2 \& p value & \multicolumn{4}{|c|}{7.04} & \multicolumn{2}{|r|}{38.70} & \multicolumn{2}{|c|}{$<0.001 * *$} \\
\hline \multicolumn{9}{|l|}{ Time of starting breast feeding } \\
\hline Correct & 16 & 26.7 & 15 & 25.0 & 57 & 95.0 & 15 & 25.0 \\
\hline Incorrect & 44 & 73.3 & 45 & 75.0 & 3 & 5.0 & 45 & 75.0 \\
\hline - X2 \& p value & \multicolumn{4}{|c|}{0.04} & \multicolumn{2}{|c|}{61.25} & \multicolumn{2}{|c|}{$<0.001 * *$} \\
\hline \multicolumn{9}{|l|}{ Number of Breast Feeding/Day } \\
\hline - 4-7 time / day & 17 & 28.3 & 20 & 33.3 & 7 & 11.7 & 19 & 31.7 \\
\hline - 8 -12 time / day & 6 & 10.0 & 9 & 15.0 & 36 & 60.0 & 12 & 20.0 \\
\hline - $\quad>12$ & 37 & 61.7 & 31 & 51.7 & 17 & 28.3 & 29 & 48.3 \\
\hline X2 \& p value & \multicolumn{2}{|r|}{1.37} & \multicolumn{2}{|c|}{0.50} & \multicolumn{2}{|c|}{20.66} & \multicolumn{2}{|c|}{$<0.001 * *$} \\
\hline \multicolumn{9}{|l|}{ The ideal way to breast feeding } \\
\hline - $\quad$ Complete \& Correct & 9 & 15.0 & 3 & 5.0 & $\mathbf{5 0}$ & 83.3 & 5 & 8.3 \\
\hline - Incomplete \&Correct & 51 & 85.0 & 54 & 90.0 & 10 & 16.7 & 52 & 86.7 \\
\hline - Don't Know \& incorrect & $\mathbf{0}$ & 0.0 & 3 & 5.0 & $\mathbf{0}$ & 0.0 & 3 & 5.0 \\
\hline X2 \& p value & \multicolumn{2}{|c|}{6.08} & \multicolumn{2}{|c|}{0.04} & & 68.27 & & \\
\hline Indicators of Their Infant Hunger & & & & & & & & \\
\hline - $\quad$ Complete \& Correct & 29 & 48.3 & 21 & 35.0 & 55 & 91.7 & 21 & 35.0 \\
\hline - Incomplete \&Correct & 31 & 51.7 & 39 & 65.0 & 5 & 8.3 & 39 & 65.0 \\
\hline - $\quad$ Don't Know \& incorrect & $\mathbf{0}$ & 0.0 & $\mathbf{0}$ & 0.0 & $\mathbf{0}$ & $\mathbf{0 . 0}$ & $\mathbf{0}$ & 0.0 \\
\hline X2 \& p value & & 19 & & 13 & & 41.48 & & \\
\hline signs of adequate lactation: & & & & & & & & \\
\hline - $\quad$ Complete \& Correct & 9 & 11.7 & 3 & 5.0 & 52 & 86.7 & 5 & 8.3 \\
\hline - Incomplete \&Correct & 44 & 73.3 & 36 & 60.0 & 8 & 13.3 & 36 & 60.0 \\
\hline
\end{tabular}




\begin{tabular}{|c|l|l|l|l|l|l|l|l|}
\hline - Don't Know \& incorrect & $\mathbf{7}$ & $\mathbf{1 5 . 0}$ & $\mathbf{2 1}$ & $\mathbf{3 5 . 0}$ & $\mathbf{0}$ & $\mathbf{0 . 0}$ & $\mathbf{1 9}$ & $\mathbf{3 1 . 7}$ \\
\hline X2 \& p value & 10.80 & \multicolumn{4}{|l|}{0.05} & 75.57 & $<0.001^{* *}$ & \\
\hline
\end{tabular}

Table (4): Distribution of the Samples According To Their Practices Regarding Breast Feeding.

\begin{tabular}{|c|c|c|c|c|c|c|c|c|}
\hline \multirow[t]{3}{*}{ Variable } & \multicolumn{4}{|c|}{$\begin{array}{c}\text { Pre } \\
\text { intervention }\end{array}$} & \multicolumn{4}{|c|}{$\begin{array}{c}\text { Post } \\
\text { Intervention }\end{array}$} \\
\hline & \multicolumn{2}{|c|}{$\begin{array}{r}\text { Study group } \\
\mathrm{n}=60\end{array}$} & \multicolumn{2}{|c|}{$\begin{array}{r}\begin{array}{r}\text { Control group } \\
n=60\end{array} \\
\end{array}$} & \multicolumn{2}{|c|}{$\begin{array}{r}\text { Study group } \\
\mathbf{n}=60\end{array}$} & \multicolumn{2}{|r|}{$\begin{array}{r}\text { Control group } \\
n=60\end{array}$} \\
\hline & No & $\%$ & No & $\%$ & No & $\%$ & No & $\%$ \\
\hline \multicolumn{9}{|c|}{ Breasts Hygiene Before Feeding: } \\
\hline Yes & 14 & 23.3 & 11 & 18.3 & 50 & 83.3 & 15 & 25.0 \\
\hline No & 46 & 76.7 & 49 & 81.7 & 10 & 16.7 & 45 & 75.0 \\
\hline X2 \& p value & \multicolumn{4}{|c|}{$\begin{array}{ll}0.45 & 0.50 \\
\end{array}$} & \multicolumn{4}{|c|}{$\begin{array}{ll}41.11 & <0.001 * *\end{array}$} \\
\hline \multicolumn{9}{|c|}{ Newborn Positions During Feeding } \\
\hline Done correct & 13 & 21.7 & 15 & 25.0 & 54 & 90.0 & 18 & 30.0 \\
\hline Done incorrect & 47 & 78.3 & 45 & 75.0 & 6 & 10.0 & 42 & 70.0 \\
\hline X2 \& p value & \multicolumn{4}{|c|}{$\begin{array}{ll}0.18 & 0.66\end{array}$} & \multicolumn{4}{|c|}{$45.00<0.001^{* *}$} \\
\hline \multicolumn{9}{|l|}{ Position of the mouth: } \\
\hline Nipple & 43 & 71.7 & 35 & 58.3 & 3 & $\mathbf{5 . 0}$ & 26 & 43.3 \\
\hline Nipple and areola & 17 & 28.3 & 25 & 41.7 & 57 & 95.0 & 34 & $\begin{array}{clll}56.7 & & & \end{array}$ \\
\hline X2 \& p value & 2.34 & 0.12 & & & 24.05 & & $001 * *$ & \\
\hline \multicolumn{9}{|l|}{ Breast Feeding Is Practiced: } \\
\hline Bilateral & 17 & 28.3 & 16 & 26.7 & 54 & 90.0 & 20 & 33.3 \\
\hline unilateral & 43 & 71.7 & 44 & 73.3 & 6 & 10.0 & 40 & 66.7 \\
\hline X2 \& p value & 0.04 & 0.83 & & & 40.75 & & $001^{* * *}$ & \\
\hline \multicolumn{9}{|l|}{ Duration of Lactation: } \\
\hline - $<10$ & 29 & 48.3 & 29 & 48.3 & 0 & 0.0 & 5 & 8.3 \\
\hline $\begin{array}{lll}\text { - } & 10- & \text { minutes } \\
\end{array}$ & 30 & 50.0 & 24 & 40.0 & 2 & 3.3 & 34 & 56.7 \\
\hline - $\quad 15-\quad$ minutes & 1 & 1.7 & 7 & 11.7 & 19 & 31.7 & 12 & 20.0 \\
\hline - $\quad 20-45$ minutes & 0 & 0.0 & 0 & 0.0 & 39 & 65.0 & 9 & 15.0 \\
\hline T \& p value & 5.16 & 0.07 & & & 53.77 & $<0.001$ & & \\
\hline
\end{tabular}

Table (5): Distribution of the Samples according To Their Knowledge about the mastitis

\begin{tabular}{|c|c|c|c|c|c|c|c|c|}
\hline \multirow[t]{3}{*}{ Variable } & \multicolumn{4}{|c|}{$\begin{array}{c}\text { Pre } \\
\text { intervention }\end{array}$} & \multicolumn{4}{|c|}{$\begin{array}{c}\text { Post } \\
\text { Intervention }\end{array}$} \\
\hline & \multicolumn{2}{|c|}{$\begin{array}{c}\text { Study group } \\
\mathbf{n}=\mathbf{6 0}\end{array}$} & \multicolumn{2}{|c|}{$\begin{array}{c}\text { Control group } \\
\mathbf{n}=60\end{array}$} & \multicolumn{2}{|c|}{$\begin{array}{c}\text { Study group } \\
\mathbf{n}=\mathbf{6 0}\end{array}$} & \multicolumn{2}{|c|}{$\begin{array}{c}\text { Control group } \\
\mathbf{n}=\mathbf{6 0}\end{array}$} \\
\hline & No & $\%$ & No & $\%$ & No & $\%$ & No & $\%$ \\
\hline \multicolumn{9}{|l|}{ Definition of mastitis } \\
\hline Complete \& Correct & 4 & 6.7 & 5 & 8.3 & 41 & 68.3 & 9 & 15.0 \\
\hline Incomplete \&Correct & 38 & 63.3 & 32 & 53.3 & 19 & 31.7 & 33 & $\mathbf{5 5 . 0}$ \\
\hline Don't Know \& incorrect & 18 & 30.0 & 23 & 38.3 & $\mathbf{0}$ & 0.0 & 18 & 30.0 \\
\hline $\mathrm{X}^{2} \& \mathrm{p}$ value & 1.23 & \multicolumn{3}{|c|}{25} & \multicolumn{2}{|c|}{42.24} & \multicolumn{2}{|c|}{$<0.001 * *$} \\
\hline \multicolumn{9}{|l|}{ Causes of mastitis } \\
\hline - Complete \& Correct & 3 & $\mathbf{5 . 0}$ & 7 & 11.7 & 38 & 63.3 & 8 & $\mathbf{1 3 . 3}$ \\
\hline Incomplete \&Correct & 33 & $\mathbf{5 5 . 0}$ & 23 & 38.3 & 22 & 36.7 & 27 & 45.0 \\
\hline Don't Know \& incorrect & 24 & 40.0 & 30 & $\mathbf{5 0 . 0}$ & $\mathbf{0}$ & 0.0 & 25 & 41.7 \\
\hline $\mathrm{X}^{2} \& \mathrm{p}$ value & \multicolumn{2}{|l|}{4.05} & \multicolumn{2}{|c|}{0.13} & \multicolumn{2}{|c|}{45.07} & \multicolumn{2}{|c|}{$<0.001 * *$} \\
\hline \multicolumn{9}{|l|}{ Signs and Symptoms of mastitis : } \\
\hline - $\quad$ Complete \& Correct & 18 & 30.0 & 6 & 10.0 & 50 & 83.3 & 10 & 16.7 \\
\hline Incomplete \&Correct & 39 & 65.0 & 45 & 5.0 & 10 & 16.7 & 43 & 71.7 \\
\hline Don't Know \& incorrect & 3 & 5.0 & 9 & 15.0 & 0 & 0.0 & 7 & 11.7 \\
\hline $\mathrm{X}^{2} \& \mathrm{p}$ value & \multicolumn{4}{|c|}{$9.42 \quad 0.009$} & \multicolumn{2}{|c|}{54.21} & \multicolumn{2}{|c|}{$<0.001 * *$} \\
\hline \multicolumn{9}{|l|}{ breastfeeding during mastitis } \\
\hline - Yes & 9 & 15.0 & 7 & 11.7 & 57 & 95.0 & 11 & 18.3 \\
\hline No & 51 & 85.0 & 53 & 88.3 & 3 & 5.0 & 49 & 81.7 \\
\hline$X^{2} \& p$ value & \multicolumn{2}{|l|}{0.28} & \multicolumn{2}{|l|}{0.59} & \multicolumn{3}{|c|}{71.81} & $<0.001 * *$ \\
\hline \multicolumn{9}{|l|}{ Preventive measures of mastitis } \\
\hline - Complete \& Correct & 6 & 10.0 & 10 & 16.7 & 47 & 78.3 & 10 & 16.7 \\
\hline - Incomplete \&Correct & 35 & 58.3 & 27 & 45.0 & 13 & 21.7 & 27 & 45.0 \\
\hline Don't Know \& incorrect & 19 & 31.7 & 23 & 38.3 & 0 & 0.0 & 23 & 38.3 \\
\hline $\mathrm{X}^{2} \& \mathrm{p}$ value & 2.41 & & & 29 & 51.9 & & $<0.0$ & 1 ** \\
\hline \multicolumn{9}{|c|}{ Self-care of mastitis } \\
\hline Complete \& Correct & 6 & 10.0 & 3 & 5.0 & 38 & 63.3 & 3 & 5.0 \\
\hline - Incomplete \&Correct & 21 & 35.0 & 26 & 43.3 & 22 & 36.7 & 26 & 43.3 \\
\hline - Don't Know \& incorrect & 33 & 55.0 & 31 & 51.7 & 0 & 0.0 & 31 & 51.7 \\
\hline X2 \& p value & \multicolumn{4}{|c|}{0.45} & 61.2 & & \multicolumn{2}{|c|}{$<0.001 * *$} \\
\hline
\end{tabular}


Table(6)Distribution of the Samples according To Their signs and symptoms of mastitis .

\begin{tabular}{|c|c|c|c|c|c|c|c|c|}
\hline \multirow[t]{3}{*}{ Variable } & \multicolumn{4}{|c|}{$\begin{array}{c}\text { Pre } \\
\text { intervention }\end{array}$} & \multicolumn{4}{|c|}{$\begin{array}{c}\text { Post } \\
\text { Intervention }\end{array}$} \\
\hline & \multicolumn{2}{|c|}{$\begin{array}{c}\text { Study group } \\
\mathbf{n}=\mathbf{6 0}\end{array}$} & \multicolumn{2}{|c|}{$\begin{array}{c}\begin{array}{c}\text { Control group } \\
n=60\end{array} \\
\end{array}$} & \multicolumn{2}{|c|}{$\begin{array}{c}\text { Study group } \\
\mathbf{n}=\mathbf{6 0}\end{array}$} & \multicolumn{2}{|c|}{$\begin{array}{c}\text { Control group } \\
n=60\end{array}$} \\
\hline & No & $\%$ & No & $\%$ & No & $\%$ & No & $\%$ \\
\hline \multicolumn{9}{|l|}{ Scoring of pain } \\
\hline - non & $\mathbf{0}$ & 0.0 & $\mathbf{0}$ & 0.0 & 52 & 86.7 & 11 & 18.3 \\
\hline - mild & 15 & 25.0 & 15 & 25.0 & 8 & 13.3 & 19 & 31.7 \\
\hline -moderate & 24 & 40.0 & 22 & 36.7 & $\mathbf{0}$ & 0.0 & 30 & 50.0 \\
\hline -sever & 21 & 35.0 & 23 & 38.3 & $\mathbf{0}$ & 0.0 & $\mathbf{0}$ & 0.0 \\
\hline X2 \& p value & \multicolumn{4}{|c|}{0.17} & \multicolumn{4}{|c|}{61.16} \\
\hline \multicolumn{9}{|l|}{ Scoring of redness } \\
\hline - non & $\mathbf{0}$ & 0.0 & $\mathbf{0}$ & 0.0 & $\mathbf{5 0}$ & 83.3 & 17 & 28.3 \\
\hline - mild & 15 & 25.0 & 18 & 30.0 & 10 & 16.7 & 26 & 43.3 \\
\hline -moderate & 25 & 41.7 & 22 & 36.7 & $\mathbf{0}$ & 0.0 & 17 & 28.3 \\
\hline -sever & 20 & 33.3 & 20 & 33.3 & $\mathbf{0}$ & 0.0 & $\mathbf{0}$ & 0.0 \\
\hline $\mathbf{X}^{2} \& \mathbf{p}$ value & \multicolumn{4}{|c|}{0.46} & \multicolumn{2}{|c|}{40.36} & \multicolumn{2}{|c|}{$<0.001^{* *}$} \\
\hline \multicolumn{9}{|l|}{ Scoring of oedema } \\
\hline - non & $\mathbf{0}$ & 0.0 & $\mathbf{0}$ & 0.0 & 53 & 88.3 & 21 & 35.0 \\
\hline - mild & 13 & 21.7 & 12 & 20.0 & 7 & 11.7 & 29 & 48.3 \\
\hline -moderate & 36 & 60.0 & 40 & 66.7 & $\mathbf{0}$ & 0.0 & 10 & 16.7 \\
\hline -sever & 11 & 18.3 & 8 & 13.3 & $\mathbf{0}$ & 0.0 & $\mathbf{0}$ & 0.0 \\
\hline $\mathbf{X}^{2} \& \mathbf{p}$ value & \multicolumn{4}{|c|}{0.72} & \multicolumn{4}{|c|}{37.28} \\
\hline \multicolumn{9}{|l|}{ Scoring of pyrexia } \\
\hline - non & $\mathbf{0}$ & 0.0 & $\mathbf{0}$ & 0.0 & 58 & 96.7 & 27 & 45.0 \\
\hline - mild & 9 & 15.0 & 15 & 25.0 & 2 & 3.3 & 31 & 51.7 \\
\hline -moderate & 45 & 75.0 & 36 & 60.0 & $\mathbf{0}$ & $\mathbf{0 . 0}$ & 2 & 3.3 \\
\hline -sever & 6 & $\mathbf{1 0 . 0}$ & 9 & 15.0 & $\mathbf{0}$ & 0.0 & $\mathbf{0}$ & $\mathbf{0 . 0}$ \\
\hline$X^{2} \& p$ value & \multicolumn{4}{|c|}{3.10} & \multicolumn{2}{|c|}{38.79} & \multicolumn{2}{|c|}{$<0.001 * *$} \\
\hline
\end{tabular}

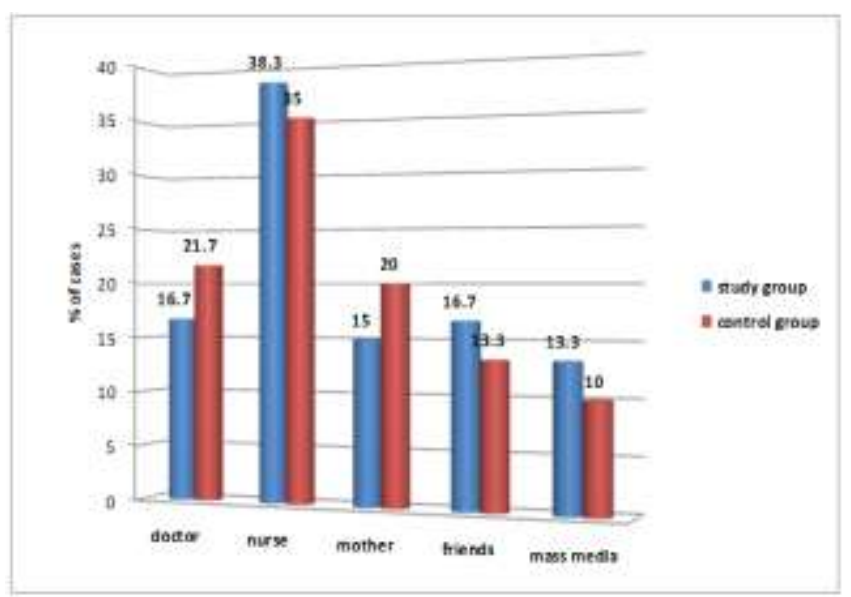

Figure (2): Percentage distribution of mothers regarding Source of information

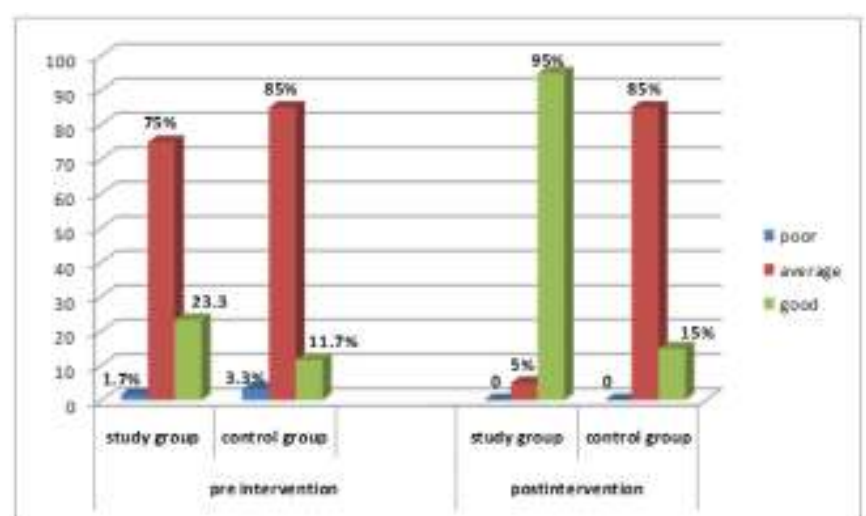

Figure 3): percentage distribution of the study sample total knowledge score regarding breastfeeding during mastitis 


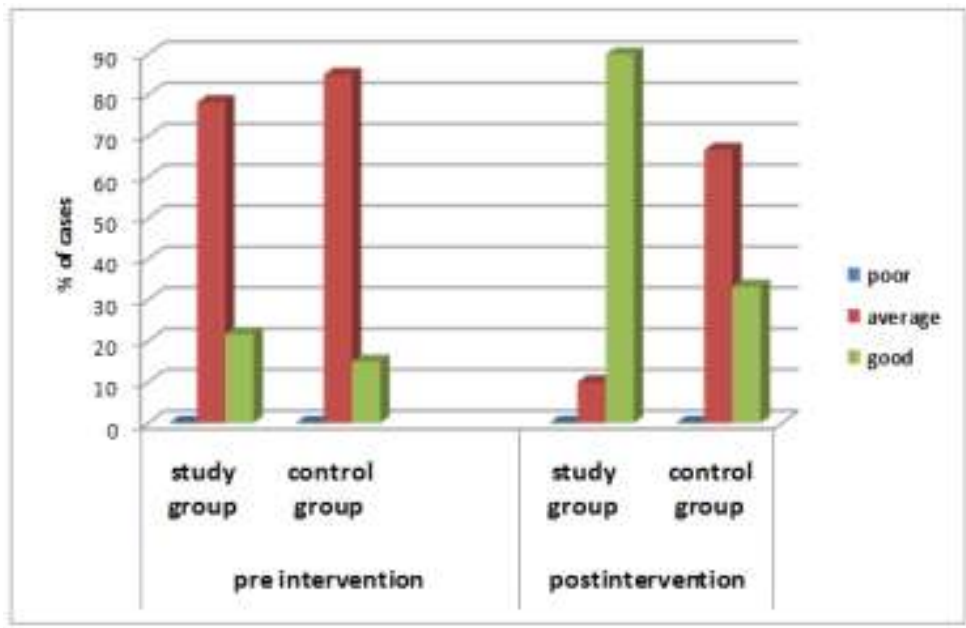

Figure (4): percentage distribution of the study sample total practice score regarding breastfeeding during mastitis

Table (7): Relation between total knowledge "pre" Practice and total practice pre intervention improvement between study and control group pre intervention

\begin{tabular}{|c|c|c|c|c|c|c|}
\hline \multirow{2}{*}{ Variable } & \multicolumn{2}{|c|}{$\begin{array}{c}\text { Knowledge of Study group } \\
\text { n=60 }\end{array}$} & \multicolumn{2}{c|}{ Knowledge of Control group } \\
n=60
\end{tabular}

Table (8): Relation between total knowledge "post" Practice and total practice post intervention improvement between study and control group post intervention $(n=60)$.

\begin{tabular}{|c|c|c|c|c|c|c|}
\hline \multirow{2}{*}{ Variable } & \multicolumn{3}{|c|}{$\begin{array}{c}\text { Study group } \\
\mathbf{n}=\mathbf{6 0}\end{array}$} & \multicolumn{3}{|c|}{$\begin{array}{c}\begin{array}{c}\text { Control group } \\
n=60\end{array} \\
\end{array}$} \\
\hline & \multicolumn{3}{|c|}{ Total knowledge post } & \multicolumn{3}{|c|}{ Total knowledge post } \\
\hline Total practice post intervention & poor & average & good & poor & average & good \\
\hline - $\quad$ average & 0.0 & $21(80.8 \%)$ & $2(5.9 \%)$ & 0.0 & $40(81.63 \%)$ & $4(36.4 \%)$ \\
\hline - $\quad$ good & 0.0 & $5(19.2 \%)$ & $32(94.1 \%)$ & 0.0 & $9(18.36 \%)$ & $7(63.6 \%)$ \\
\hline$X^{2} \& p$ value & \multicolumn{3}{|r|}{$<0.001 * * *$} & \multicolumn{3}{|r|}{$<0.001 * * *$} \\
\hline
\end{tabular}

\section{Discussion}

Puerperal mastitis is the inflammation of the breast in connection with pregnancy, breastfeeding or weaning. Some predisposing factors are known but their predictive value is minimal. It appears that proper breastfeeding technique, frequent breastfeeding and avoidance of stress are the most important factors that can be influenced (Kvist, et al., 2008).

The traditional management of breast abscess involves incision and drainage of pus along with antistaphylococcal antibiotics, but this is associated with prolonged healing time, regular dressings, difficulty in breastfeeding, and the possibility of milk fistula, and unsatisfactory cosmetic outcome (Rizzo, et al., 2009).

The purpose of this article was to evaluate the effectiveness of nursing intervention measures on minimizing Puerperal mastitis and promoting breast feeding.

Support to initiate breastfeeding and on an ongoing basis are important because it has been shown that breastfeeding rates decrease with a decrease in breastfeeding support. Lack of support results in problems of establishment of breastfeeding, breast engorgement, sore or cracked nipples; usually due to poor technique (Stamp 2006). De Oliveira et al ,2006 also demonstrated in their randomised controlled trial that there was no difference between women who were counselled once in hospital and those who were not counselled on breastfeeding. This suggests that ongoing support is crucial if breastfeeding is to be successful .In particular, one-to-one, needs-based, informal repeat sessions, and generic formal antenatal education were effective in increasing breastfeeding rates. Needs based, informal peer support, whether ante-natal or post-natal were particularly effective in increasing initiation rates (Dyson, et al., 2005). 
The role of nurses has included clinical nursing practices, consultation, follow-up treatment, patient education and illness prevention. This has improved the availability of health-care services, reduced symptoms of chronic diseases, increased cost effectiveness and enhanced customers' experiences of health-care services (Virpi Kemppainen, et al., 2012).In addition, health promotion by nurses can lead to many positive health outcomes including adherence, quality of life, patients' knowledge of their illness and self-management (BoschCapblanc et al., 2009). However, because of the broad field of health promotion, more research is needed to examine the role of health promotion in nursing (Whitehead, 2011).

In present study the highest percentage in age group (45.0\%) in age group 20-25yrs. And (33.3\%) in control group respectively. This agree with (Eapen \& Fernandes,2013) who reported The present study shows that the mean age of the sample was $26.6 \pm 4.3$ years old and thirty-four percent of them were highly educated. Regarding the effectiveness of an information booklet on measures for managing breast metastasis. They reported that the highest percentage of mothers were in the age group of twenty-four to twenty-nine years old, twenty-seven percent in the age group of 18-23 years, twenty percent were between 30-35 years and five percent were above thirty-five years of age. The educational status reveals that the majority of them completed high education, and thirty percent completed primary school.In present study in study group there were increase in study group in knowledge about breast feeding after intervention than control group with moderate significance difference $(\mathrm{P}<0.001)$ about initiate breast feeding, importance of colostrum milk, time starting breast milk, and time and method of breast feeding. This agree with study (Al-Binali, 2012 ) who reported mothers educated as WHO instruction Only 119 of the participants (31\%) complied with the WHO recommendations of starting breastfeeding within one hour of delivery (Petit AI, 2010). In present study post intervention knowledge about breast feeding in study group $(86.7 \%)$ about knowledge of importance of breast feeding \& important of colostrum milk were $(86.7 \%) \%(75.0 \%)$. This agree with (Nabulsi, et al., 2011) who found Three hundred forty three $(89.3 \%)$ of the participants reported that colostrum is good for the baby, while $5(1.3 \%)$ consider it either not good or possibly detrimental to the child's health and $36(9.4 \%)$ don't know the answer.

In present study there was significance difference between study \& control groups after intervention about number of breast feeding/day. This agree with (Kamal Kataria, et al., 2013 ) who reported emptying the breast: This important aspect of the management of puerperal breast infection is sometimes ignored. The breast may be emptied either by suckling or by expression. Although bacteria are present in the milk, no harm appears to be done to the infant if breastfeeding is continued.Regular natural milk emptying of the breast is an essential part of the treatment. Breast emptying with mechanical devices is recommended only for a subareolar localization of the abscess, or when the drain or dressing placement renders natural feeding impossible (Rizzo, et al., 2009). In such cases, mother can continue breastfeeding from the other breast, and the affected breast must be emptied mechanically. The milk from that breast may be given to the baby without pasteurization if it does not contain pus or blood. Such a procedure is also safe for the baby because mother's milk provides immunological protection by the oral supply of specific antibody and immune competent cells acting against mother's causative (Ip, et al., 2007).Breastfeeding should be maintained as it does not pose any risks to healthy full-term infants. Maintaining lactation is important for treating the abscess. There are several studies showing that breastfeeding is safe for the infant (Renfrew, et al., 2012).

Any factor that favors the stagnation of breast milk predisposes to the development of mastitis, including scheduled feedings, sudden change in the number of feedings, infant's long sleep period at night, use of pacifiers or bottles, failure to completely empty the breast, short frenulum, infant with a poor suck, excessive milk production, separation of mother and infant, and abrupt weaning (Kramer, 2010). Maternal fatigue facilitates the development of mastitis. Women who have already had mastitis in the current lactation or in previous lactations are more susceptible to developing other mastites, due to the broken integrity of the junction between alveolar cells (Nabulsi, 2011). In present study when comparison between study \& control groups after intervention there were moderate significance $(\mathrm{P}<0.001)$ with highly Proper emptying of the breast is the most important part of the treatment for mastitis, with maintenance of breastfeeding and manual milk expression after feedings, if necessary. Despite the presence of bacteria in breastmilk, in case of mastitis, breastfeeding should be maintained, as it does not pose any risks to healthy full-term infants (Britton, et al., 2007)

In present study there were highly significance difference between study and control groups after intervention in practice of care of breast with mastitis this view in score of pain scoring of redness, oedema and pyrexia. This agrees with (Elsa 2004\& Giugliani, 2004) who found Besides antibiotic therapy and complete emptying of the affected breast, the following measures are also part of the treatment: maternal rest (preferably in bed), analgesics or non-steroidal anti-inflammatory drugs such as ibuprofen, and abundant intake of fluids. Warm compresses before feedings can help drain the milk, whereas cold compresses after feedings or short intervals help relieve the symptoms. Other useful measures to minimize discomfort include offering the unaffected breast first and wearing a well-fitting bra. As mastitis is quite painful, with involvement of the general health status, emotional support should always be part of the treatment (Hall, 2011). 


\section{Conclusion and recomendations}

The breastfeeding intervention of health care professionals must be adapted to an effective program, 20-hour breastfeeding training course, and puerperal mastitis should be accepted as a public health care issue.

\section{References}

[1]. Al-Binali A. M. , Breastfeeding knowledge, attitude and practice among school teachers in Abha female educational district, southwestern Saudi Arabia, Int Breastfeed J. 2012; 7: 10.

[2]. Amir LH; Academy of Breastfeeding Medicine Protocol Committee.

[3]. Breastfeed Med. 2014 Jun;9(5):239-43. doi: 10.1089/bfm.2014.9984.

[4]. PMID: 24911394

[5]. Andrews JI, Fleener DK, Messer SA, et al. The yeast connection: Is Candida linked to breastfeeding associated pain? Am J Obstet Gynecol 2007;197:424.e1-424.e4.

[6]. Bosch-Capblanc X., Abba K., Prictor M., Garner P. Contracts between patients and healthcare practitioners for improving patients' adherence to treatment, prevention and health promotion activities. The Cochrane Database of Systematic Reviews 2009;2007:1-73.

[7]. Britton C, McCormick FM, Renfrew MJ, Wade A, King SE: Support for breastfeeding mothers. Cochrane Database Syst Rev 2007, Issue 1:Art. No.: CD001141.pub 3.

[8]. Christensen B.L.,Kockrow E.O.,(2011):Foundations of nursing ,6thed.,MOSBY Elsevier,USA.,P.902.

[9]. Crepinsek MA, Crowe L, Michener K, et al; Interventions for preventing mastitis after childbirth. Cochrane Database Syst Rev. 2012 Oct 17;10:CD007239. doi: 10.1002/14651858.CD007239.pub3.

[10]. De Oliveira L.D. Effect of intervention to improve breastfeeding technique on frequency of exclusive breastfeeding and lactationrelated problems. Journal of Human Lactation. 2006;22(3):315-21.

[11]. Dyson L., McCormick F.M., Renfrew M.J.: Interventions for promoting the initiation of breastfeeding. Cochrane Database Syst Rev. 2005, Issue 2: Art. No.: CDD001688

[12]. Eapen S.S., Fernandes P. Effectiveness of an Information Booklet on Home Remedial Measures For Breast Engorgement. Nitte University Journal of Health Science. 2013; 3(3).

[13]. Elsa R. J.\& Giugliani, Common problems during lactation and their management, J. Pediatr. (Rio J.) vol.80 no.5 suppl. Porto Alegre Nov. 2004.

[14]. Giugliani E.R.J. Slow weight gain/failure to thrive. In: Walker M, editor. Lactation Consultant Core Curriculum. Boston: Jones and Bartlett Publishers; 2004. p. 332-55.

[15]. Hall J.: Effective community-based interventions to improve exclusive breastfeeding at four to six months in low and middleincome countries: a systematic review of randomised controlled trials. Midwifery 2011, 27:497-502.

[16]. Inch S., Renfrew MJ. Common breastfeeding problems. In: Effective Care in Pregnancy and Childbirth (Chalmers I, Enkin M, Keirse M, eds.), Oxford University Press, Oxford, UK, 2005, pp. 1375-1389.

[17]. Ip S, Chung M, Raman G, Chew P, Magula N, DeVine D, Trikalinos T, Lau J: Breastfeeding and maternal and infant health outcomes in developed countries. Evid Rep Technol Assess 2007, 153:1-186.

[18]. Jahanfar S., Ng CJ, Teng CL : Antibiotics for mastitis in breastfeeding women. Cochrane Library. Syst.Rev.(7)2010.

[19]. Jeanne,P\& Spencer, (2008):Management of Mastitis in Breastfeeding Women, Am Fam Physician. Sep 15;78(6):727-731.

[20]. Kamal Kataria , Anurag Srivastava, and Anita Dhar, Management of Lactational Mastitis and Breast Abscesses: Review of Current Knowledge and Practice, Indian J Surg. 2013 Dec; 75(6): 430-435.

[21]. Kelly, A. \&McGarry(2012): The 5-Minute Consult Clinical Companion to Women's Health, post partum mastitis, Lippincott Williams \& Wilkins, p.124

[22]. Kramer M.S.: "Breast is best": the evidence. Early Hum Dev 2010, 86:729-732.

[23]. Kvist, Linda J.; Larsson, Bodil; Hall-Lord, Marie; Steen, Anita; Schalén, Claes (1 January 2008). "The role of bacteria in lactational mastitis and some considerations of the use of antibiotic treatment". International Breastfeeding Journal. 3 (1): 6.

[24]. Lawrence RA. The puerperium, breastfeeding, and breast milk. Curr Opin Obstet Gynecol 2008;2:23-30.

[25]. McKinney, E.Se\&murray, s.s.(2014): foundation of maternal newborn and women's health nursing, 6th edition, Elsevier Saunders ,USA,P612-613

[26]. Michie C, Lockie F, Lynn W.(2013): The challenge of mastitis.Archives of Disease in Childhood, 88,(9):818-21. [:1468-2044 (Electronic)

[27]. Nabulsi M.: Why are breastfeeding rates low in Lebanon? A qualitative study. BMC Pediatr 2011, 11:75.

[28]. Neifert MR. Clinical aspects of lactation: Promoting breastfeeding success. Clin Perinatol 2006;26:281-306.

[29]. Newman, J.,(2009):Blocked Ducts \& Mastitis, international breast feeding centre

[30]. http://nbci.ca/index.php?option=com_content\&view=article\&id=7:blocked-ducts-a-mastitis\&catid=5:information\&Itemid=17

[31]. Petit A.I. Perception and knowledge on exclusive breastfeeding among women attending antenatal and postnatal clinics. A study from Mbarara Hospital-Uganda, August 2008. Dar Es Salaam Medical Student's Journal. 2010;16(1):27-30.

[32]. Renfrew M.J., McCormick FM, Wade A, Quinn B, Dowswell T: Support for healthy breastfeeding mothers with healthy term babies. Cochrane Database Syst Rev 2012, 5, CD001141.

[33]. Rizzo M., Peng L., Frisch A. Breast abscesses in nonlactating women with diabetes: clinical features and outcome. Am J Med Sci. 2009;338(2):123-126

[34]. Spencer J. (2014):Management of Mastitis in Breastfeeding Women (American Family Physician April 15,727.

[35]. Stamp GE, Cassanova HT. A breastfeeding study in rural population in South Australia. Rural Remote Health. 2006;6(2):495.

[36]. Thompson J. (2009):Breastfeeding: benefits and implications. Part two. Community Practitioner, 78, (6):218-9. [1462-2815 (Print)]

[37]. Virpi Kemppainen, Kerttu Tossavainen and Hannele Turunen, Nurses' roles in health promotion practice: an integrative review, Health Promot. Int. (2012) doi: 10.1093/heapro/das034.

[38]. Waldenstrom U., Aarts C. Duration of breastfeeding and breastfeeding problems in relation to length of postpartum stay: A longitudinal cohort study of a national Swedish sample. Acta Paediatr 2011;93:669-676.

[39]. Walker M. Mastitis in lactating women. Lactation Consultant Series Two. La Leche League International, Schaumburg, IL, 2009; Unit 2.8.

[40]. Whitehead D.Health promotion in nursing: a Derridean discourse analysis. Health Promotion International 2011;26:117-127. 